\title{
Os militares e os usos políticos do abolicionismo
}

\author{
The Brazilian Military and the political uses of abolitionism
}

\author{
Rodrigo Goyena Soares \\ Universidade de São Paulo (USP), São Paulo, SP, Brasil
}

RESUMO: O artigo discute o sentido do abolicionismo militar na crise do Império. Malgrado sua heterogeneidade, a caserna foi mais uníssona quanto à abolição do que em outras matérias ideológicas. Sem prejuízo das razóes corporativas, foram sobretudo motivos políticos que levaram o segmento militar a endossar o fim do cativeiro. $\mathrm{O}$ argumento assenta-se sobremaneira na releitura da imprensa militar e da correspondência civil, fontes nas quais o abolicionismo castrense se afigura como mecanismo de ingresso na política nacional: compreendeu-se a aboliçẫo como medida de enfraquecimento da classe dirigente e, portanto, como forma de introduzir novos rostos na administração pública.

PALAVRAS-CHAVE: Militares. Abolicionismo. Imprensa militar. Política imperial. Crise do Império.

ABSTRACT: The article discusses the meaning of military abolitionism during the crisis of the Brazilian Empire. Despite its heterogeneity, the military corporation was more united in what concerns abolition than in other ideological matters. Notwithstanding corporate reasons, political pleadings above all led the military segment to advocate the end of slavery. The argument is based on a reinterpretation of the military press and the civil correspondence, sources in which military abolitionism appears as a mechanism for gaining political leverage: abolition was understood as a measure to weaken the ruling class, and thereafter as a form to introduce new faces in public administration.

KEYWORDS: Military. Abolitionism. Military press. Imperial politics. Crisis of the Brazilian Empire.

\footnotetext{
* Pesquisador da Universidade de São Paulo, Faculdade de Filosofia, Letras e Ciências Humanas, Departamento de História, São Paulo, SP, Brasil. Doutor em História Social pela Universidade Federal do Estado do Rio de Janeiro (UNIRIO). E-mail: rodrigo.goyenasoares@usp.br. https://orcid.org/0000-0003-1389-0930.
}

O autor agradece à Fundação de Amparo à Pesquisa do Estado de São Paulo (FAPESP), processo ㄲo 2017/12748-0 relativo à bolsa de pós-doutorado, e também a Renato Lemos pela leitura crítica do texto. 


\section{Introdução}

O ano de 1869 pareceu começar sob bons augúrios, pelo menos do ponto de vista externo. O Império e seus aliados entravam na etapa final da Guerra do Paraguai (1864-1870), que seria tão somente uma caçada a Solano López. Assunção estava tomada, e o ditador paraguaio, pensava-se no Rio de Janeiro, se encastelaria nos pântanos chaquenhos por algumas rápidas semanas antes de ser definitivamente capturado pelas tropas brasileiras. Apesar das expectativas lisonjeiras, a guerra alastrou-se por mais um ano. O que importava, no entanto, não era mais o desfecho final do combate. Era, sobretudo, o pós-guerra. No âmbito externo, se a guerra havia unido argentinos a brasileiros - e a uruguaios também -, a paz parecia agora separá-los. No interno, as relações do governo imperial com as Forças Armadas, especialmente com o Exército, poderiam mostrar-se embaraçosas. Ainda durante a guerra, oficiais inferiores deram suas provas emancipacionistas, que somente se avolumaram nas décadas de 1870 e de 1880 . O preço de recrutar libertos para o conflito no Prata teria de ser pago. Deixava-o claro o jornal O Século XIX, cujo proprietário era um veterano que se dizia porta-voz dos Voluntários da Pátria. ${ }^{1}$ Mais emblemático, porém, foi um artigo de maio de 1871, publicado no ultraconservador Diário do Rio de Janeiro, folha ministerial cuja circulação ultrapassava os cinco mil exemplares (MOLINA, 2015, p. 228):

Legaremos a nossos filhos a miséria e a vergonha de possuir o Brasil, ainda em 1871, brasileiros escravos. Tem-se por demais discutido a emancipação dos escravos; cumpre redigir o ultimatum, e este deve correr por conta da espada [...]. O militar é gente da verdade in re, já teve ocasião de avaliar os nossos patrícios libertos na Guerra do Paraguai; ao soldado, pois, (melhor do que os senhores), que conhece o ex-escravo na defesa da própria vida e na desafronta da pátria ultrajada, ao soldado, dizemos, compete a ação da emancipação do brasileiro escravo! [...] Sejam todos os escravos nascidos no Brasil, do dia 7 de Setembro de $1871 \mathrm{em}$ diante, acompanhados das mães, entregues nas colônias militares e arsenais da Marinha e da Guerra, onde deverá haver estabelecimentos de criação e de educação para eles, até se acharem em estado de prestar serviços, quer nas armas, quer nas artes respectivas, quer nas colônias de agricultura, privativas do militar. Nada de ficarem os nascidos em poder dos protetores (ex-senhores). Morrerão todos. Nada de se conservarem escravas as mães dos novos cidadãos. É tirania. [...] Assina: a Espada. ${ }^{2}$

Embora anônimo, o artigo não era inofensivo. Não poderia ter sido uma figura militar anódina o autor daquelas palavras: a hierarquia militar o perseguiria e, ainda, a folha defensora do gabinete ministerial não as teria publicado. O artigo vinha do alto oficialato, quiçá Osório ou Câmara, o que deixava entrever que aquela não era a posição de um oficial isolado, mas de um grupo expressivo do Exército, numérica e hierarquicamente. Também alarmantes eram as palavras que, naquele mesmo mês de janeiro de 1869, o Visconde do Rio Branco escreveu ao Imperador. Em carta pessoal e reservada, o diplomata, que estava prestes a rumar ao Paraguai para lá erguer um governo provisório, dizia que nos jornais dos Estados Unidos, e especialmente no New York Herald, se profetizava uma revolução no Brasil, cujo maior legado, independentemente da vitória no Paraguai, seria a instituição de um regime republicano. ${ }^{3}$ No final de 1870 , soube-se de um plano do capitão Pompílio de Albuquerque para derrubar o trono em cooperação com o recém-fundado 
partido republicano, justamente quando Dom Pedro II organizava sua primeira viagem ao exterior. Floriano Peixoto, aparentemente, teria sido secretamente aliciado (HOLANDA, 2004, p. 374).

No plano menos acontecimental e, portanto, da longa duração, o Império dava sinais de desgaste naquele começo de 1870. Inaugurou-se, após a Guerra do Paraguai, uma fase de sucessivas crises políticas que, estruturalmente, acenavam para reorientaçóes nas matrizes econômicas e para o advento de uma nova dinâmica social. O eixo produtivo cafeeiro deslocava-se para o Oeste Paulista, introduzindo, direta ou indiretamente, potenciais novos rostos nas instituições de governo. O corpo social também apresentava modificações: o número de cativos havia decrescido, não alcançando mais do que $15 \%$ da população do Império, e a classe média urbana, fruto da expansão do capital ligado à indústria, às finanças e aos serviços, havia tomado maiores proporçôes.

O momento, e pelo menos até o início da era republicana, bem exemplifica o que Antonio Gramsci denominou de interregno, isto é, um período de duração determinada em que a velha ordem já se rompeu, mas a nova ainda não se estruturou. Seria um tempo de insegurança, em que a previsibilidade dos acontecimentos políticos se veria ameaçada. A razão dessa imprevisibilidade não estaria em outro lugar senão na erosão do que era usual e na fragilidade do que ainda não se constituiu. Não à toa, Gramsci caracterizou a fase de interregno, principalmente, como tempo de abertura para cadeias inesperadas de acontecimentos. Em sentido mais amplo, o período seria expressão de uma crise de hegemonia, no qual os grupos dirigentes teriam fracassado em promover reformas basilares, que atendessem às mudanças nas estruturas socioeconômicas. Nesse sentido, grupos sociais não alinhados com os partidos tradicionais - ou, inclusive, com novas frações da classe dirigente - tenderiam a deles separar-se, julgando-os pouco representativos das novas classes sociais (GRAMSCI, 1978, p. 55).

Se não a mais determinante, o abolicionismo foi a razão matricial da passagem para a nova ordem. O combate ao cativeiro redundou numa relativa homogeneização, pelo menos no sentido ideológico, dos grupos políticos e sociais tradicionalmente pouco representados nas principais instâncias de tomada de decisão. Médicos, engenheiros, advogados ou inclusive pequenos comerciantes, caixeiros, sapateiros e militares assumiram a bandeira da abolição antes do que, notadamente, os cafeicultores paulistas e os republicanos fluminenses. Contudo, por trás das vacilaçóes de cada grupo - que respondiam a interesses econômicos próprios a cada classe -, compreendeu-se a abolição como recurso de poder. Pôr fim ao cativeiro significaria impactar severamente o já moroso coração econômico do Império, o complexo cafeeiro do Rio de Janeiro. E, se devidamente atingido, poderia haver uma renovação dos grupos dirigentes.

Para os militares, a equação era socioeconômica apenas no segundo plano. A abolição poderia significar um incremento de mão de obra disponível para as indústrias, cujo estímulo figurava entre as prioridades da caserna. Todavia, o abolicionismo militar não contemplou o que hoje poderíamos chamar de políticas públicas de reparação ao cativo, e isso em que pesem as expectativas laudatórias que o artigo de maio de 1871 deixava supor. Pelo contrário, as Forças Armadas passaram ao largo das agendas de integração dos libertos na sociedade de classes, que não deixaram de constar na pluralidade de sociedades e associações abolicionistas que emergiram entre o final da década de 1870 e a de 1880 (SANTOS, 2018, p. 194). Para o segmento militar, o abolicionismo não era uma dívida social, mas uma política de poder, o que, de resto, se tornou mais visível quando alcançaram o governo em 1889. 


\section{O abolicionismo militar em perspectiva historiográfica}

Não por acaso, os militares eram francamente mais uníssonos em relação ao fim do cativeiro do que em outras matérias ideológicas. $\mathrm{O}$ apadrinhamento de teses positivistas não foi matéria consensual no Exército, ainda menos na Armada. E, quando essas teses foram integradas, houve adaptação a gosto próprio, conforme o grupo militar. Benjamin Constant, recorda Renato Lemos, compreendia o positivismo de maneira eclética e pessoal, de uma forma que não correspondia com exatidão a como seus superiores ou inferiores positivistas se valeram dos princípios de Augusto Comte (LEMOS, 1999, p. 225). O republicanismo tampouco era a regra. Se havia mais certezas na Escola Militar do que no alto oficialato, nas ponderaçóes de Celso Castro, o republicanismo não era conceito de acepção única. Pelo contrário, era plural, inclusive na corporação militar. Daí o autor recorrer à expressão grupos de militares no lugar de os militares, marcando assim suas distinções internas (CASTRO, 1995, p. 9).

Sobre o abolicionismo, contudo, Lemos e Castro, ainda que implicitamente, não interpóem distinçốes entre militares. De forma assertiva, John Schulz vislumbra na abolição o fator de solidariedade entre gerações e hierarquias militares, tese que June Hahner ratifica (SCHULZ, 1994; HAHNER, 1975). Mais explicitamente, Wilma Peres Costa aponta, sem negar algum sentimento humanitário no oficialato, a dimensão estrutural da oposição entre o Exército e a escravidão. Para a autora, a aversão da caserna à escravidão adviria, sobretudo, da vulnerabilidade externa do Brasil, vislumbrada na guerra contra um Estado, o Paraguai, cujo Exército de conscrição universal fazia ressaltar, na escravidão, a causa fundamental do despreparo militar do Império. Em contraste, o recrutamento no Brasil, seletivo e restrito, era feito nas camadas populares, quando não entre escravos, como na Guerra do Paraguai. Seria, pois, na contradição entre o sistema escravista e a existência de um Exército profissional de característica nacional que teria emergido o abolicionismo nas Forças Armadas (COSTA, 1996, p. 292). Nelson Werneck Sodré tampouco discorda da centralidade da escravidão no que diz respeito à oposição entre os militares, em sua pluralidade, e os governos imperiais. No entanto, a razão do abolicionismo militar não seria exclusivamente a dimensão corporativa salientada por Costa, mas, também, o espírito de solidariedade com os cativos, advindo do congraçamento entre militares e libertos nos campos de batalha (SODRÉ, 2010, p. 196).

Do alto ao baixo oficialato - ou entre praças, também -, o abolicionismo era pauta amplamente consensual, embora mais sistematizada no Exército do que na Armada. Fosse na imprensa ou nos clubes e institutos que fundaram ou aos quais se associaram, os militares mostravam-se, especialmente em relação ao cativeiro, unidos em sua pluralidade. Quanto a isso, eram os militares, e não grupos de militares. Vislumbraram nas reformas servis de 1871 e de 1885 - quais sejam, a Lei do Ventre Livre e a Lei dos Sexagenários - apenas reformas paliativas, que atendiam, ao fim e ao cabo, ora aos interesses da classe senhorial instituída no poder, ora às fraçóes dessa classe que, embora mais heterodoxas sobre a escravidão, eram julgadas reformistas demais e revolucionárias de menos. As mudanças servis, por conseguinte, não eram enxergadas como fracassos dos grupos dirigentes em ajustar os interesses dos governantes àqueles dos governados, mas como estratégias de perpetuação no comando político.

Sem prejuízo da dimensão corporativa do abolicionismo, que certamente pesou na luta militar contra o cativeiro, propóe-se nas páginas a seguir que o abolicionismo castrense tinha, em primeira instância, uma dimensão política. Tratava-se de uma via de acesso ao poder. O recrutamento de 
ex-escravos, durante a Guerra do Paraguai, provocou reaçóes negativas nas Forças Armadas, não tanto por um suposto - e mistificado - espírito humanitário entre a oficialidade e os libertos, mas porque se buscavam refundações corporativas que viessem a enaltecer o prestígio da instituição militar. O aliciamento de ex-cativos - ou, ainda, de fragmentos das classes populares - não era precisamente o que daria atratividade à caserna, mas justamente o contrário. As reformas corporativas eram fundamentais, notadamente quanto ao recrutamento. Não obstante, elas emperravam num sistema político-partidário pouco afeito, mais oficiosa do que oficialmente, a dar voz aos militares. Se a abolição da escravatura era a janela de oportunidades para ascender ao poder e, assim, conduzir as reformas desejadas, o melhor, para os militares, era apressar a ordem dos acontecimentos.

Era maneira, como se não bastasse, de dar fôlego a um programa de reformas que incluía a industrialização, a urbanização, a secularização, reformas eleitorais e migratórias, a integração física do país, a instrução pública, o protecionismo comercial e o emissionismo monetário. $\mathrm{O}$ abolicionismo apresentava-se à caserna como mecanismo de ingresso na política nacional, para a realização de objetivos também nacionais. Com o imenso benefício de ser uma campanha popular, os militares tomaram o abolicionismo como forma de vincularem-se às camadas populares e médias, constituindo um discurso que associava o militar ao povo, à purificação das instituiçóes e à refundação do país. A opção republicana, em seus variados matizes, surgia como alternativa para erguer a nova ordem, dando-se mais como oposição à monarquia do que como forma igualitária de governo. Não sem razão, o silêncio militar sobre a integração do ex-escravo na ordem republicana contrastou com o ruído - e a efetiva realização - das reformas corporativas tão logo o Império desmoronou.

\section{A dimensão corporativa do abolicionismo}

Poucos dias antes do Quinze de Novembro de 1889, Benjamin Constant procurou Deodoro da Fonseca para convencê-lo a liderar a implantação da República. Os veteranos do Paraguai entenderam-se e organizaram uma reunião que incluiu os nomes de Quintino Bocaiúva, Rui Barbosa, Francisco Glicério e alguns oficiais da Armada. Naquele 11 de novembro, as forças estruturais de oposição à monarquia pareceram personificar-se em nomes pontuais. Os republicanos fluminenses, os federalistas, a cafeicultura paulista e os militares insatisfeitos concordaram em indicar o nome de Deodoro, então marechal-de-campo, para chefiar o movimento insurreto. A escolha não era fortuita. Entre os tenentes-generais, o Visconde de Pelotas - tão atuante quanto Deodoro na Questão Militar - poderia ser um bom nome. Havia também Hermes Ernesto da Fonseca, irmão de Deodoro e pai do futuro presidente da República Hermes Rodrigues da Fonseca, ou Manuel de Almeida Lobo d'Eça, entre os demais marechais-de-campo. Nenhum deles, no entanto, tinha a expressividade corporativa de Deodoro.

O primeiro presidente da República foi um homem da caserna. Tão logo assumiu a presidência, reajustou os salários militares e começou a empreender reformas corporativas julgadas, há tempos, urgentes. Antes disso, Deodoro havia-se empenhado na defesa de Sena Madureira e de Cunha Matos na Questão Militar, o que lhe valeu, pouco depois, a presidência do Clube Militar, fundado em 1887. Era visto como um militar troupier, de melhor trânsito castrense do que o Visconde de Pelotas e certamente mais expressivo, no sentido corporativo, do que Hermes Ernesto da Fonseca ou do que o já velho Lobo d'Eça. Ou seja, Deodoro era o melhor nome, do ponto de vista civil, 
por sua popularidade na tropa e, sob a perspectiva militar, porque não deixaria em segundo plano os anseios da corporação.

Um deles era a abolição da escravatura. Ainda antes da Guerra do Paraguai, a imprensa militar não se furtou a pregar reformas que remodelassem o sistema de recrutamento. Dizia-se, na década de 1850, que o Exército e a Armada eram compostos pelas camadas mais humildes da população, constituídas de negros, índios ou miscigenados. ${ }^{4}$ Não se falava então abertamente da abolição - tema que, na ocorrência, estava alijado da pauta política -, mas se conclamava por uma tropa racialmente mais branca e socialmente mais abastada. O ímpeto higienizador bem se coadunava com as críticas à escravidão, vislumbrada como tolhimento à imigração e à modernização do Império.

O oficialato, não sem interpor críticas à classe dominante, advogava a ampliação do fluxo migratório europeu, em primeiro lugar, porque se acreditava que haveria, assim, uma purificação do sangue nacional em detrimento da escravatura, julgada preguiçosa e moralmente imprópria. ${ }^{5}$ O pano de fundo, todavia, era o prestígio da caserna. A defesa da imigração e as críticas ao trabalho servil davam-se a fim de enaltecer a corporação. Se atalhados pela obrigatoriedade e pela universalidade do serviço militar, a imigração e o declínio do cativeiro poderiam redundar numa recomposição das Forças Armadas, que, então, deixariam de ser percebidas como depósito dos socialmente indesejados ou como destino de último recurso.

A Guerra do Paraguai reacendeu os ânimos entre a caserna e a classe dirigente. O entusiasmo pelo conflito, que não durou mais do que um ano, transformou-se em aversão pelo recrutamento, que, ao declinar continuadamente ao longo do conflito, recaiu inevitavelmente sobre as camadas populares (GOYENA SOARES, 2017, p. 50). Agravando o cenário, em novembro de 1866 decretou-se medida que abria as portas para a libertação de escravos que participassem da guerra. $\mathrm{O}$ número de libertos recrutados para a guerra não alcançou números expressivos. Não mais do que 10.000 libertos rumaram ao Prata, quando o total de combatentes imperiais superou o número de 130.000 (SALLES, 1990, p. 63). No entanto, os impactos simbólicos do decreto de 1866 nas Forças Armadas não foram menores. Havia incomodado a inclusão de ex-escravos numa tropa pouco prestigiada pelo Império. Havia irritado a associação entre o destino do cativo e o da corporação. Havia perturbado fazer do escravo o defensor do Império. Não sem razão, quando a guerra terminou, a imprensa - da menos à mais liberal - trouxe a público a oposição dos militares ao cativeiro e o amparo que eles davam aos projetos de emancipação do ventre escravo.

As iniciativas mais radicais foram rapidamente aplacadas. No início de 1871, correram rumores na Corte a respeito de uma revolução no Rio Grande do Sul capitaneada por ninguém menos do que o general Osório, o que o herói do Prata desmentiu apressadamente. ${ }^{6}$ De forma quiçá mais grave, Marciano, irmão de Benjamin Constant, fundou o Grêmio do Porvir naquele mesmo ano de 1871. Objetivava-se fazer propaganda republicana e abolicionista no Exército por intermédio da associação, o que permaneceu letra morta devido às hesitaçôes da Fortaleza de Santa Cruz, especialmente, quanto ao republicanismo. Pouco depois, fundava-se também na Corte o Instituto Militar, cujas principais lideranças eram Floriano Peixoto, Feliciano Benjamin, Barreto Niemeyer, Jacques Ourique, Sena Madureira, Oliveira Guimarães e Severiano da Fonseca - outro irmão de Deodoro. Embora a instituição se dissesse orientada para o melhoramento da corporação, houve temores quanto à sua provável politização - não só no sentido abolicionista -, e foi extinta por decisão do Conselho de Estado pouco meses após sua criação. ${ }^{7}$ 
A participação na Guerra do Paraguai conferiu aos oficiais inferiores um sentido de unidade mais articulado do que no pré-guerra. O tributo de sangue alegou-se, então, deveria redundar em melhorias na corporação. O primeiro passo nesse sentido - e renovando os clamores das décadas que precederem à guerra contra López - seria uma lei de recrutamento que não recaísse sobre libertos ou sobre as classes populares, mas sobre o conjunto da população, aí incluídos, em termos de renda, grupos médios e altos. Quanto a isso, o Estado-Maior não se opôs. Pelo contrário, apoiou a oficialidade inferior. Fizeram coro ao pressionar os gabinetes imperiais para tornar a caserna atrativa, o que significava, de entrada, melhores soldos.

O Visconde do Rio Branco, que esteve no Paraguai e percebeu a insatisfação dos setores castrenses, conduziu uma série de reformas que buscaram se prestar, direta ou indiretamente, ao apaziguamento dos ânimos militares. Em primeiro lugar, tão logo assumiu a presidência do Conselho de Ministros editou a Lei do Ventre Livre, o que significava, embora de forma apenas tangencial, atender aos apelos abolicionistas do oficialato mais radical. Em segundo, Rio Branco editou, em 1873, decreto que reajustou os salários militares, do simples soldado ao marechal do Exército $^{8}$, e outorgou pequeno salário e moradia aos alunos da Escola Militar, que reabria após a Guerra do Paraguai. Logrou proibir as punições corporais no Exército, que usualmente eram associadas às chibatadas impingidas aos escravos, e mostrou-se disposto a fazer o mesmo para a Armada, ainda que com menor êxito. De forma ainda mais solícita, promulgou, em 1874, a Lei de Recrutamento. Pelo novo dispositivo, o recrutamento forçado e aleatório era substituído pelo serviço militar obrigatório, mediante tipo de sorteio que recairia sobre parcelas mais amplas, em termos socioeconômicos, da população.

O resultado foi pouco auspicioso, pelo menos no entender dos militares. A Lei do Ventre Livre foi compreendida apenas como analgésico, sem efetivos impactos sobre a emancipação: pelas disposições da medida, davam-se mais sessenta anos - até 1930, portanto - para a real abolição, que se daria quase por inércia, isto é, na medida do decréscimo natural da população cativa nascida antes do 28 de setembro de 1871, data da promulgação da lei. Foi o que denunciou a imprensa militar, especialmente $O$ Soldado e a Tribuna Militar, no início da década de $1880 .{ }^{9}$ Não eram aquelas palavras de menor expressividade, a considerar que ambos os periódicos contavam, entre seus principais colaboradores, com oficiais superiores das Forças Armadas, notadamente, o deputado e futuro senador Alfredo d'Escragnolle Taunay, o tenente-coronel Sena Madureira, o contra-almirante Arthur Silveira da Mota e o tenente-coronel Catão Roxo. Eram jornais, de outra maneira, que refletiam também as aspirações de quadros mais radicais do Exército, como Floriano Peixoto, Tibúrcio de Sousa e Sólon Ribeiro. ${ }^{10}$

Condenou-se, também, o reajuste salarial, que não acompanhou a evolução galopante da inflação, fruto de uma política fiscal expansionista adotada durante e após a guerra contra o Paraguai. Como se não bastasse, a Lei do Recrutamento tampouco agradou. Embora pertinente em princípio, revelou-se inoperante na prática, pois permitia a compra de substitutos, afora extensas exceçôes que diziam respeito aos bacharéis, a médicos e grandes proprietários rurais, a estratos da classe média, como os pequenos comerciantes e, ainda, aos que possuíam dependentes. Em suma, o recrutamento continuou a recair sobre as camadas populares, quando não sobre ex-escravos. Pesava, também, o ritmo lento das promoções, que eram julgadas injustas (SCHULZ, 1994, p. 213). Para agravar ainda mais o relacionamento entre a caserna e o governo, o efetivo das Forças Armadas foi reduzido praticamente pela metade após a guerra. Não sem vínculo com essa redução, houve 
corte de despesas no Ministério da Guerra e da Marinha. Se, antes da guerra, as Forças Armadas recebiam em torno de $35 \%$ do orçamento imperial, após o conflito o percentual não ultrapassou de forma continuadamente declinante até 1888 - os 15\%; e isso, quando a receita total do Império mais do que triplicou entre 1864 e 1888 (CARREIRA, 1980, p. 34).

Até o regresso dos liberais ao poder em 1878 - e inclusive depois -, os militares julgaramse desprezados pelo poder civil, para quem a garantia de despolitização da caserna dependia da capacidade de mantê-la em estado de hibernação (COELHO, 1976, p. 34). Sucedeu ao gabinete conservador do Visconde do Rio Branco o igualmente conservador Caxias, que não se mostrou inclinado a introduzir modernizações significativas na corporação, em que pese sua tradição militar. O novo chefe de governo, que acumulava também a pasta da Guerra, talvez estivesse cansado e velho demais para compreender os novos ventos que sopravam nas Forças Armadas. O gabinete seguinte, que foi o do liberal Cansanção de Sinimbu, apresentou melhores cartas aos militares, pois Osório assumiu a pasta da Guerra. No entanto, o general muito provavelmente mais popular do Exército pouco pôde contra uma Assembleia resolutamente favorável à contenção de gastos castrenses. No início de 1879, as comissóes legislativas da Marinha e da Guerra apresentaram a debate projeto para reduzir o contingente militar no intuito de poupar o orçamento imperial. Tornando o cenário mais tenso, veio à tona, no mesmo ano, regulamento que proibia aos militares se expressarem por intermédio da imprensa.

A resposta das Forças Armadas veio a galope. Um punhado de quadros médios das guarniçóes gaúchas do Exército lançou dois jornais, O Rebate e Alvorada. No primeiro, que era significativamente mais militante, embora parecido em teor ao segundo, o jovem capitão Joaquim de Salles Torres Homem uniu-se ao coronel Arthur Oscar de Andrade Guimarães e a seu irmão o major Carlos Eugênio, ambos veteranos da Guerra do Paraguai, para lançar uma bravata ao governo: "os militares [...] não hesitarão em ser os maiores revolucionários, se esses falsos representantes do povo conseguirem pôr em execução o seu tão almejado plano [...]” ${ }^{11}$ A bravata poderia ter permanecido tão somente isso, se oficiais de maior envergadura não tivessem vindo ao socorro dos gaúchos. Ergueram-se igualmente em defesa da corporação o major Sena Madureira, o tenente-coronel Jacques Ourique, o capitão-de-mar-e-guerra Eduardo Wandenkolk e o comandante Saldanha da Gama (LEMOS, 1999, p. 309). Houve algumas punições e, inclusive, a suspensão dos jornais quando alcançaram o quinto número. Foram essas determinações vindas diretamente de Osório que, no entanto, confirmaram a primeira vitória da caserna contra o poder civil: a proposta parlamentar foi deixada de lado, quando transitava em segunda discussão.

O Rebate e Alvorada, que, ao fim e ao cabo, abriram passagem a OSoldado a Tribuna Militar, foram claros sinais de politização das Forças Armadas. Não se falava exclusivamente da corporação para a corporação, mas dela e da política nacional para ela e para a população do Império. Naquelas poucas tiragens de $O$ Rebate, condenaram-se os déficits orçamentários, os empréstimos constantes, os novos impostos e, sobretudo, a corrupção dos civis. Advogou-se a industrialização e a imigração. Falou-se também da abolição, não mais no sentido do recrutamento, das contradições expostas na Guerra do Paraguai ou, em suma, do prestígio das Forças Armadas, mas, sobretudo, em perspectiva nacional. Em seu último número, $O$ Rebate propôs a criação de um partido político militar, de matriz republicana, que deveria organizar comícios eleitorais por guarnição provincial, onde, em primeira instância, se fariam eleições primárias.

O partido político militar permaneceu letra morta, mas não por isso as Forças Armadas deixaram de assumir funções partidárias elementares. Forjou-se certa concepção do país, que 
rapidamente tomou forma de um projeto, ainda que com frouxidóes programáticas, de governo e de Estado. O papel militar deveria ser o de atualizar - e de tornar efetivas - as possibilidades de realizar uma refundação nacional. Dito de outra maneira, tratava-se, pelo menos na compreensão da caserna, de tornar real o que existia somente como potencialidade. $\mathrm{O}$ partido, nesse sentido, não seria político, mas ideológico, o que coincide, em boa medida, com a acepção gramsciana de partido. Para ele, o partido não se resumiria à entidade que aspira, eleitoralmente ou não, ao poder. Trata-se, também, de um lugar de representação e de mediação, onde se definem os interesses das classes sociais (GRAMSCI, 1978, p. 93).

Em chave política diferente, pois nem marxista, nem muito menos gramsciana, Alain Rouquié também faz a distinção entre partido político e ideológico, compreendendo que, assim como para Gramsci um jornal pode cumprir as funções de um partido, as Forças Armadas também podem operar no mesmo sentido. O partido militar, como conceito, não seria mera retórica ou provocação, mas o entendimento das Forças Armadas como força política que realiza, por outros meios, as funções essenciais dos partidos eleitorais: possuem processos de deliberação interna, de tomada de decisão e de articulação de interesses, com vistas a soerguer um projeto de poder (ROUQUIÉ, 1980, p. 10).

A concepção de país que o segmento militar operou no final da década de 1870 colidia francamente com as bases fundacionais do Império. À grande lavoura interpunham a industrialização; à crise de mão de obra, a imigração; à Igreja, a secularização; ao livre-comércio, o protecionismo comercial; à ortodoxia monetária, o emissionismo correspondente; e, sem surpresas, à subsidiariedade das Forças Armadas, sua profissionalização. A realização do projeto passava tanto pelo enfraquecimento daqueles que o tolhiam quanto pela assunção de uma posição partidária. Nesse sentido, abolicionismo e republicanismo combinaram-se, dando expressividade política ao radicalismo militar, molecular e ainda fragilmente organizado no início da década de 1870 .

\section{O abolicionismo militar como projeto de poder}

Temendo eventual movimento contrarrevolucionário, o governo provisório, assim que se constituiu com a Proclamação da República, deu quarenta e oito horas para que a família imperial fizesse as malas e deixasse o Brasil. O Imperador não resistiu, e, a bordo do cruzador Parnaiba, rumou para o sul da antiga província do Rio de Janeiro, onde se fez o transbordo para o paquete Alagoas, que levou em exílio a dinastia imperial à Europa. Ainda no porto do que viria a ser o novo Distrito Federal, a Imperatriz Tereza Cristina, atônita, perguntou ao oficial da embarcação "que diabos [havia] a família imperial [feito] para que fosse tratada como criminosa”. ${ }^{12}$ A Princesa Isabel imiscuiu-se na conversa, e Palmeira, o comandante do Parnaiba, mencionou os conflitos com as Forças Armadas. Referiu-se, sobretudo, à disposição imperial em submetê-las à captura de escravos foragidos. Alegou igualmente que - embora esperasse que a transferência de poder, julgada por ele necessária, se fizesse pela via eleitoral - o governo descuidou das reivindicações populares, encastelando-se nas aspirações daqueles que estavam no poder havia décadas. Pouco depois, quando já embarcados no Alagoas, o Conde d'Eu confessou à sua esposa, a Princesa Isabel, que o Quinze de Novembro "não o admirou, nem o surpreendeu, senão por sua demora: esperava-o desde que [havia terminado] a guerra contra o Paraguai”. ${ }^{13}$ 
Ainda que teleológicas, as palavras do Conde d'Eu evidenciavam que o golpe de Quinze de Novembro não fora obra de um oportunismo de curto prazo. Destoavam de uma abordagem que tende a personalizar a Proclamação da República e a resumi-la às hesitações de Deodoro da Fonseca. Os militares estavam, ainda que não exclusivamente, no cerne do desgaste estrutural do Império, em imensa medida, devido aos usos políticos que fizeram do abolicionismo. O Conde d'Eu não o expressou de forma tão explícita, mas o deixava entender, haja vista a associação que vislumbrou, ainda nos campos do Paraguai, entre abolição e politização das Forças Armadas (GOYENA SOARES, 2017, p. 15). Para o oficialato militar, inclusive os mais moderados, havia uma estreita relação entre o Estado imperial e os grandes proprietários escravocratas. A elite imperial, que a caserna apelidava de casacas, não estava destacada da esfera econômica. As medidas emancipacionistas, tímidas demais, testemunhavam mais oportunas concessões circunstanciais ou táticas em benefício de um novo acúmulo de poder do que o compromisso dessa elite com a erradicação do cativeiro.

Pelo contrário, as forças políticas dominantes eram percebidas como originárias e representantes, direta ou indiretamente, da agricultura escravista. Era o que salientava a Tribuna Militar em julho de 1881:

O que dissemos do fazendeiro de café aplica-se [...] ao fazendeiro do açúcar, aos potentados das províncias do Norte, aos estancieiros do Sul etc. [...]. Eles e os negociantes formam a massa da gente [...] que constituiu a nação brasileira [...], é deles que saem os deputados e os vereadores, os pais da pátria, os comendadores e os barões [...]. ${ }^{14}$

Em toada semelhante, as alas positivistas, notadamente aquelas ligadas a Miguel Lemos, estipulavam que a Câmara de Deputados era uma assembleia de fazendeiros e, se não isso, de agentes de fazendeiros. Dizia-se que o poder legislativo, em suma, não respondia às aspiraçóes nacionais e, portanto, que servia apenas para obstaculizar a opinião pública (LEMOS, 1883, p. 15).

Às vésperas da Proclamação da República, praticamente todos os oficiais - inclusive os superiores - não eram homens de grandes fortunas. Vivam de seus salários, e não da terra ou da mão de obra cativa (SCHULZ, 1994, p. 96). Compreenderam que o advento de um projeto nacional alternativo resultaria, em primeiro lugar, do enfraquecimento daqueles que entendiam como grupos dominantes, isto é, os fazendeiros. Para tanto, mister era apressar o passo abolicionista. Sem escravos, os fazendeiros não convertidos à mão de obra livre perderiam não somente o principal fator de produção, mas o capital nele empatado, a possibilidade de contrair empréstimos - condicionados, via de regra, pelo tamanho da propriedade escrava - e de renovar os ciclos produtivos. Perderiam, em suma, seus vínculos com os gabinetes e, em certos casos, sua presença no governo.

Perdendo espaço para novos rostos políticos, com produção e lucros declinantes, exportando menos e, então, pagando menos impostos, os agricultores escravocratas cederiam a centralidade que antes tinham na composição do orçamento. Não se tratava, pois, de uma empatia humanista com a escravatura, como quiseram Nelson Werneck Sodré e Sérgio Buarque de Holanda (SODRÉ, 2004, p. 275; HOLANDA, 2004), mas, sobretudo, de um projeto de poder. Não distante do espírito daquele tempo, a caserna via nos escravos "uma raça preguiçosa, voluptuosa, sem energia por educação e herança, que só pode [ria] ser estimulada por algum aguilhão”, que, não à toa, era o do Exército. ${ }^{15}$ Caberia à corporação, com o papel educador que se adjudicava, animar os espíritos 
abolicionistas e guiar a nação pelo alto: "o Estado é pai, ou deve sê-lo, [...] e o zeloso tutor que deve defender [a nação] das ganâncias [particulares]”. ${ }^{16}$

O pendor abolicionista da caserna ganhou maiores proporçóes a partir de 1880. O Soldado e a Tribuna Militar mostraram-se abertamente contrários à escravidão, publicando, reiteradamente, artigos de um curioso veterano da Guerra do Paraguai chamado Dom Obá. Este, que se dizia príncipe e que solicitava ao Imperador torná-lo embaixador do Brasil na Guiné, denunciava as condiçóes miseráveis dos antigos Voluntários da Pátria, louvava o Exército, escrevia em defesa dos operários e conclamava pela abolição (SILVA, 1997) ${ }^{17}$ A Armada não ficou para trás. Em dezembro de 1881, o periódico $O$ Marinheiro fazia apologias a Joaquim Nabuco, declarando-se contra a escravidão, embora não dispensasse a necessidade de indenização aos proprietários. ${ }^{18}$

Paralelamente à ação na imprensa, os militares atuaram no campo do associativismo. Quando não integraram sociedades abolicionistas compostas também por civis, formaram as deles. Em julho de 1881, Severiano da Fonseca assumiu a presidência do Clube de Emancipação, ligado à Escola Militar. Para a ocasião, que não era de pouca monta, organizou-se uma celebração que contou com quatrocentos convidados. Estavam presentes ninguém menos do que os abolicionistas civis João Clapp, Domingos Gomes dos Santos e J. Campos Porto, alguns dos principais nomes do Clube Abolicionista, fundado em 1883. ${ }^{19}$ Pouco depois vieram à tona o Clube Abolicionista Militar de Fortaleza e a Associação Abolicionista do 15o Batalhão de Infantaria do Ceará.

A resposta do governo, da mão do liberal João Lustosa Paranaguá, não tardou em chegar. Não somente os jornais militares deixaram de circular, mas se ordenou também a dissolução das guarnições abolicionistas. O problema, essencialmente, não era a questão servil. O próprio Paranaguá buscava encaminhá-la no poder legislativo. Tratava-se, sobretudo, de evitar uma solução de força, orquestrada pelos militares, que solapasse o emancipacionismo gradual em benefício da abolição imediata. Em meados de fevereiro de 1883 e após o 15o Batalhão ter-se declarado abolicionista, o então ministro da Guerra Carlos Afonso de Assis Figueiredo, irmão do Visconde de Ouro Preto, ordenou que a unidade fosse transferida para o Pará. Assim, substituía a guarnição cearense pelo 11으 Batalhão de Belém. Os oficiais do 15ㅇ, representados pelo tenente-coronel Francisco de Lima e Silva, redarguiram. Disseram que o batalhão se convertera em sociedade abolicionista, porque motivado pelas felicitações que o Imperador dera à Sociedade Cearense Libertadora quando libertou Acarape da escravidão. Era o primeiro município livre do Império.

Paranaguá não transigiu e, em março, embarcou o batalhão para o Pará e seu comandante para Salvador. No porto de Fortaleza, no entanto, a unidade teve sensação de vitória, uma vez que em torno de 15.000 pessoas vieram saudá-la. ${ }^{20} \mathrm{O}$ movimento espalhou-se como rastilho de pólvora. Houve adesões aos militares em Pernambuco, em Goiás, no Rio Grande do Sul e no Pará, onde o 15- Batalhão foi recebido com novas ovações. Poucas semanas depois, em maio de 1883, José do Patrocínio, João Clapp e o tenente Manuel Joaquim Pereira, não por acaso, do Ceará, articularam a Confederação Abolicionista. Em menos de três meses, a Confederação contava com dezessete clubes diferentes, representando cinco províncias e a Corte, uma ampla gama de estratos socioprofissionais e, ainda, com presença militar.

Para enfraquecer governos julgados escravocratas, a via eleitoral tampouco escapou aos setores castrenses. A Lei Saraiva, editada em janeiro de 1881, alterou o sistema eleitoral, tornando o voto direto. O antigo critério censitário permanecia inalterado - 200 mil réis anuais para os eleitores -, mas se introduziram exigências mais rígidas quanto à comprovação de renda e, sobretudo, vedou-se 
o voto aos analfabetos. Para um país no qual a taxa de alfabetização era apenas de $15 \%$ - ou de $20 \%$, se considerada apenas a população masculina -, a nova lei significava um severo impacto na participação eleitoral, o que as estatísticas não esconderam. Se em 1872 os eleitores correspondiam a $13 \%$ da população livre, em 1886 , apenas $0,8 \%$ da população total compareceu às urnas (CARVALHO, 2011, p. 395).

Estranhamente, pelo menos à primeira vista, as principais lideranças das Forças Armadas aplaudiram a excludente reforma eleitoral, quando a imprensa castrense reiteradamente associava o destino militar ao nacional ou, ainda, a caserna ao povo. Em março de 1881, numa coluna intitulada O soldado e o povo, provavelmente um oficial inferior - e radical - argumentou que a Lei Saraiva era aristocrática e contrária a todos os princípios liberais, pois arredava da urna não só os praças, mas também o povo, analfabeto. Dizia-se que o governo do liberal Saraiva queria uma nação de áulicos, de aristocratas, obstaculizando qualquer avanço real na agenda servil: "todos têm o dever de tomar parte na administração do Estado, prosseguia o articulista, porque o Estado é a grande associação constituída pelo elemento nacional”. E isso, sem exclusão do rico ou do pobre, do sábio ou do ignorante, do plebeu ou do fidalgo. Continuava, então:

A revolução não é um elemento puramente destruidor: ela traz consigo o germe da reconstituição [...]. As duas classes [os militares e o povo] ligam-se perfeitamente, e esta ligação deve-se unificar mais e mais no dia da grande reclamação de direitos. União e força: e seremos vencedores. ${ }^{21}$

As palavras do alto oficialato foram em outra direção, embora o teor geral fosse o mesmo. Para eles, a reforma eleitoral tinha uma imensa vantagem para os militares. Tolhia-se o voto aos praças, o que certamente poderia impactar negativamente as candidaturas do oficialato. Não obstante, introduzia-se a eleição direta, o que era visto em dois sentidos, um mais explícito do que o outro. Por um lado, pensava-se que a erradicação do voto em dois graus daria maior lisura ao processo eleitoral, permitindo maior transparência e, ao todo, melhores garantias de vitória militar nas urnas. Por outro lado, de forma correlata e mais implícita, as barreiras eleitorais representariam uma purificação eleitoral pela via de um liberalismo de classe. Apesar de não ser um alto oficialato francamente positivista, pairava nele o modelo do cidadão esclarecido.

No dia 21 de fevereiro de 1881, reuniram-se na Corte 41 oficiais para editar um manifesto em favor da Lei Saraiva. O Manifesto do Oficialato, se assim pudermos chamá-lo, foi assinado por ninguém outro do que o almirante Joaquim Raimundo de Lamare, o marechal-de-campo João do Rego Barros Falcão, os brigadeiros Severiano da Fonseca, Deodoro da Fonseca, Tibúrcio de Sousa, os capitães-de-mar-e-guerra Barão de Tefé e Carneiro da Rocha, os tenentes-coronéis Catão Roxo, Sena Madureira, e pelos majores Alfredo de Escragnolle Taunay e Marciano Botelho de Magalhães, para citar apenas os politicamente mais ativos. ${ }^{22}$ Do Manifesto fundou-se um Diretório Militar, que, sem ser partido eleitoral, organizou as candidaturas para as eleiçóes vindouras (ARIAS NETO, 2018). Os resultados, contudo, não foram prósperos. Na legislatura de 1881 a 1884, apenas um deputado era militar, Taunay; na de 1886 a 1889, novamente Taunay e Eusébio José Antunes. Para agravar ainda mais o cenário, os oficiais foram substituídos por civis na pasta da Guerra, ao longo da década de 1880.

$\mathrm{O}$ acirramento subsequente das tensões entre os militares e os governos imperiais está densamente analisado na historiografia. Em 1884, Sena Madureira convidou o abolicionista cearense 
Francisco do Nascimento para uma visita oficial na Escola de Tiro do Rio de Janeiro. O tenente-coronel foi punido, e o governo editou medida que proibiu aos militares se manifestarem na imprensa. Em 1885, o coronel Cunha Matos violou a medida e acusou de corrupção figuras conservadoras de quartéis piauienses. Quando preso, o alto oficialato veio-lhe ao socorro. Compreendendo que a caserna poderia ser a melhor arma na campanha abolicionista, Rui Barbosa e Quintino Bocaiúva, em maio de 1887, auxiliaram Pelotas e Deodoro a redigir um ultimato contra o gabinete do ultraconservador Cotegipe, que revogou a polêmica medida que alijava os militares da imprensa. Pouco depois, em junho do mesmo ano, formou-se o Clube Militar, que desobrigou os oficiais da tarefa de caçar escravos foragidos. ${ }^{23}$

\section{Conclusão}

Os meses que se seguiram à Abolição pareceram, pelo menos em parte, testemunhar o acerto da estratégia política castrense. A presença escravocrata nos gabinetes e na Câmara de Deputados esmoreceu sobremaneira. Em meados de junho de 1889, formou-se a última composição ministerial do Império, que não teve sequer uma figura ligada à antiga classe senhorial. $\mathrm{Na}$ Assembleia, também houve ampla renovação, malgrado o Senado vitalício. As últimas eleições do Império, que se deram em 31 de agosto de 1889, caracterizaram-se por uma acachapante vitória liberal. A novidade, no entanto, estava nos rostos que passaram a compor a Câmara. Em que pese às reiteradas fraudes eleitorais, nada menos do que $55 \%$ dos deputados gerais eram novos, sem experiência qualquer, tampouco, em outras instâncias superiores, como os ministérios, o Senado e o Conselho de Estado. Bem certo é que a deputação geral era o primeiro passo, na carreira administrativa do Império, para ascender aos cargos de maior prestígio. Nas eleiçóes de agosto, contudo, não se afigurou sobremaneira o acúmulo de cargos eleitorais ou administrativos que tradicionalmente marcou o Segundo Reinado. Ratificando a novidade, eram deputados novos também no sentido etário. ${ }^{24}$

A vitória de agosto, no entanto, foi apenas parcial. O avanço liberal deu-se tão somente como mecanismo para impedir o republicano. O Visconde de Ouro Preto parecia endossar a reforma pelo alto, já que, de forma a manter docilizada a lavoura tanto paulista quanto fluminense, autorizou a emissão de novos créditos agrícolas. Em relação à corporação militar, o último chefe de gabinete do Império nomeou o Visconde de Maracaju e o Barão de Ladário, respectivamente, para as pastas da Guerra e da Marinha. Embora moderados, eram militares de carreira. Ainda, aceitou proposta para conceder títulos de nobreza aos marechais-de-campo. Paralelamente e também no sentido de uma modernização conservadora, elaborou projeto para reformar a Guarda Nacional de maneira a reequilibrá-la em detrimento das Forças Armadas. A caserna radical então compreendeu o sentido de oportunidade e de urgência que a hora apresentava. Se Ouro Preto pusesse em prática sua agenda reformista - que excluía a federação, clamor primeiro dos republicanos paulistas, não previa a industrialização e rebaixava a corporação militar -, pouco mudaria para que tudo permanecesse como antes. O clima era de agora ou nunca. Numa aliança que se mostrou insustentável na década de 1890, os republicanos paulistas aliaram-se à caserna, e rapidamente deram-se as reunióes secretas que levaram à queda do Império. 


\section{Referências}

ARIAS NETO, José Miguel. Imprensa militar: ciência, tecnologia e política no Império. In: BARBOSA, J. R.; VIANA, M. A. G.; GONÇALVES, L. P.; CUNHA, P. R. (org.). Militares e política no Brasil. São Paulo: Expressão Popular, 2018.

CARREIRA, Liberato de Castro. História financeira e orçamentária do Império do Brasil. Brasília, DF: Senado Federal; Rio de Janeiro: Fundação Casa de Rui Barbosa, 1980.

CARVALHO, José Murilo de. A construção da ordem: a elite política imperial. Teatro de sombras: a política imperial. Rio de Janeiro: Civilização Brasileira, 2011. p. 395.

CASTRO, Celso. Os militares e a República. Um estudo sobre cultura e ação política. Rio de Janeiro: Zahar, 1995.

COELHO, Edmundo Campos. Em busca de identidade: o Exército e a Política na sociedade brasileira. Rio de Janeiro: Forense Universitária, 1976.

COSTA, Wilma Peres. A espada de Dâmocles. O Exército, a Guerra do Paraguai e a crise do Império. São Paulo: Editora HUCITEC; Editora UNICAMP, 1996.

GOYENA SOARES, Rodrigo (org.). Diário do Conde d'Eu, comandante em chefe das tropas brasileiras em operação na República do Paraguai. Rio de Janeiro; São Paulo: Paz \& Terra, 2017.

GOYENA SOARES, Rodrigo. Expectativa \& Frustração. História dos veteranos da Guerra do Paraguai. Tese (Doutorado em História) - Programa de Pós-Graduação em História, Universidade Federal do Estado do Rio de Janeiro, Rio de Janeiro, 2017.

GRAMSCI, Antonio. Cahiers de prison. Cahiers 10, 11, 12 et 13. Paris: Éditions Gallimard, 1978.

HAHNER, June. Relações entre civis e militares no Brasil (1889-1898). São Paulo: Editora Pioneira, 1975.

HOLANDA, Sérgio Buarque. O Brasil monárquico: do Império à república. v. 7. Rio de Janeiro: Bertrand Brasil, 2004. p. 374

LEMOS, Miguel. A incorporação do proletariado escravo: protesto da Sociedade Positivista do Rio de Janeiro contra o recente projeto de governo. Recife: Tipografia Mercantil, 1883.

LEMOS, Renato. Benjamin Constant. Vida e História. Rio de Janeiro: Topbooks, 1999.

MOLINA, Matías M. História dos jornais no Brasil: da era colonial à Regência (1500-1840). São Paulo: Companhia das Letras, 2015.

ROUQUIÉ, Alain (org.). Les partis militaires au Brésil. Paris: Presses de la Fondation Nationale des Sciences Politiques, 1980.

SALLES, Ricardo. Guerra do Paraguai: escravidão e cidadania na formação do Exército. Rio de Janeiro: Paz \& Terra, 1990.

SANTOS, Cláudia. O ativismo político da Confederação Abolicionista antes e depois do 13 de maio de 1888. In: LIMA, Ivana Stolze; GRINBERG, Keila; REIS, Daniel Aarão (org.). Instituições nefandas: o fim da escravidão e da servidão no Brasil, nos Estados Unidos e na Rússia. Rio de Janeiro: Fundação Casa de Rui Barbosa, 2018.

SCHULZ, John. O Exército na política. Origens da intervenção militar, 1850-1894. São Paulo: EdUSP, 1994.

SILVA, Eduardo. Dom Obá II D’África, o príncipe do povo. Vida, tempo e pensamento de um homem livre de cor. São Paulo: Companhia das Letras, 1997.

SODRÉ, Nelson Werneck. História militar do Brasil. São Paulo: Editora Expressão Popular, 2010.

\section{Notas}

\footnotetext{
${ }^{1}$ Arquivo Nacional (AN) - Diversos cód., antiga SDH, cód. 747.

2 Biblioteca Nacional (BN) - Diário do Rio de Janeiro, 15/05/1871.

${ }^{3}$ Arquivo Histórico do Museu Imperial (AHMI) - Maço 151. Doc. 7225. Visconde do Rio Branco para Dom Pedro II, Rio de Janeiro, 02/01/1869.
} 
${ }^{4} \mathrm{BN}-\mathrm{O}$ Militar, 05/04/1855.

${ }^{5}$ BN - O Militar, 26/10/55; e SCHULZ, op. cit., p. 47.

${ }^{6} \mathrm{AHMI}$ - Maço 162, doc. 7464. Visconde do Rio Branco para Dom Pedro II, Rio de Janeiro, 08/03/1871.

${ }^{7}$ AHMI - Maço 160, doc. 7440. Floriano Peixoto para o Conde d’Eu, Rio de Janeiro, 24/09/1871.

8 Ver decreto 2.105 de 08/02/1873. Disponivel em: https://www2.camara.leg.br/legin/fed/decret/1824-1899/decreto2105-8-fevereiro-1873-550416-publicacaooriginal-66369-pl.html. Acesso em: 26 abr. 2018.

${ }^{9}$ No ano de 1881, os dois periódicos condenaram reiteradamente a Lei do Ventre Livre. Ver: BN - O Soldado e Tribuna Militar, janeiro a dezembro de 1881.

${ }^{10}$ Os periódicos $O$ Soldado e Tribuna Militar, embora tenham circulado apenas de forma efêmera, foram os principais veículos de expressão pública e política da oficialidade. Ver a esse respeito: SCHULZ, op. cit., p. 87. As posições políticas da caserna foram reconstituídas, ainda que não exclusivamente, a partir da leitura exaustiva desses jornais para os anos de 1881 e de 1882, quando efetivamente transitaram no Império.

${ }^{11} \mathrm{BN}$ - O Rebate, 01/06/1879.

${ }^{12}$ Instituto Histórico e Geográfico Brasileiro (IHGB) - DL 458, doc. 6.

${ }^{13}$ IHGB - Lata 352, pasta 53. Notas pessoas da Princesa Isabel a bordo do vapor Alagoas.

${ }^{14} \mathrm{BN}$ - Tribuna Militar, 10/07/1881.

${ }^{15}$ BN - Tribuna Militar, 01/12/1882.

${ }^{16} \mathrm{BN}$ - Tribuna Militar, 18/12/1881.

${ }^{17}$ BN - Tribuna Militar, 25/09/1881 e O Soldado, 20/05/1881.

${ }^{18} \mathrm{BN}$ - O Marinheiro, 05/12/1881.

${ }^{19}$ BN - Tribuna Militar, 28/07/1881.

${ }^{20}$ BN - Gazeta da Tarde, 14/02, 22/02, 06/03 e 07/03 de 1883.

${ }^{21} \mathrm{BN}$ - O Soldado, 23/03/1881.

${ }^{22}$ A lista completa encontra-se disponível em: BN - O Soldado, 13/03/1881.

${ }^{23}$ As melhores análises sobre a Questão Militar podem ser encontradas em: CASTRO, op. cit.; LEMOS, op. cit.; e SCHULZ, op. cit.

${ }^{24}$ Para a lista de eleitos em agosto de 1889, ver: BN - O País, 02, 03, 04, 25, 26 e 27/10/1889. Para as composições legislativas anteriores, ver: JAVARI, Barão de. Organizações e programas ministeriais. Rio de Janeiro: Imprensa Nacional, 1889.

Data de recebimento: 02/02/2019

Data de aprovação: 10/10/2019 